\title{
Environmental characterization of the reproductive season of migratory fish of the Sinú river (Córdoba, Colombia)
}

\section{Caracterización ambiental de la temporada reproductiva de los peces migradores del río Sinú (Córdoba, Colombia)}

\author{
Eduardo Kerguelén-Durango, ${ }^{1}$ M.Sc, Víctor Atencio-García, ${ }^{1 *}$ M.Sc.
}

\begin{abstract}
${ }^{1}$ Universidad de Córdoba, Facultad de Medicina Veterinaria y Zootecnia, Departamento de Ciencias Acuícolas, Centro de Investigación Piscícola CINPIC, Montería, Colombia. *Correspondencia: vatencio@hotmail.com.
\end{abstract}

Received: October 2014; Accepted: February 2015.

\begin{abstract}
Objective. To characterize some abiotic factors during the reproductive season of migratory fish (bocachico Prochilodus magdalenae, dorada Brycon sinuensis, bagre blanco Sorubim cuspicaudus and barbul Pimelodus blochii) in the Sinú River. Materials and methods. From April to October, 2008, in Carrizola (Tierralta, $36.31 \mathrm{~km}$ from the Urrá hydroelectric plant) factors such as flow $=\mathrm{Q}_{\text {river' }}$ daily flow difference $=\Delta \mathrm{Q}_{\text {river }}$, velocity $=\mathrm{V}_{\text {river, }}$, temperature $=\mathrm{T}_{\text {river }}$ electrical conductivity $=\mathrm{CE}$, total dissolved solids $=S T D$, turbidity $=$ Turb, cloudiness $=$ Nub, rainfall =Pluv and solar brightness $=B$ s were measured daily three times/day $(07: 00 \mathrm{~h}, 12: 00 \mathrm{~h}, 17: 00 \mathrm{~h})$. Also, on the same schedule, ichthyoplankton was collected as an indicator of reproductive activity, assessed by reproductive frequency ( $\mathrm{Fr}=$ number of days with presence of ichthyoplankton/number of days in the period evaluated X 100) and larval density $\left(\mathrm{DI}=\right.$ larval $\left./ \mathrm{m}^{3}\right)$. Results. The daily values of $\mathrm{Q}_{\text {river }}$ ranged between 278.7 and $838.5 \mathrm{~m}^{3} / \mathrm{s}, \Delta \mathrm{Q}_{\text {river }}$ between 0.0 and $100.7 \mathrm{~m}^{3} / \mathrm{s}, \mathrm{V}_{\text {river }}$ between 1.40 and $1.53 \mathrm{~m} / \mathrm{s}$, Pluv between 0.0 and $88.2 \mathrm{~mm}, \mathrm{~T}_{\text {river }}$ between 27.0 and $28.7^{\circ} \mathrm{C}$, STD between 73.0 and $302.3 \mathrm{mg} / \mathrm{L}$, Turb between 9.7 and $679.7 \mathrm{NTU}$, CE between 81.0 and $361.7 \mathrm{mS} / \mathrm{cm}$, Bs between 0.0 and 11.2 hours, Nub between 2.0 and 7.3 octaves. The Fr was $30.4 \%$, with April (40.0\%) and May (74.2\%) as the higher activity reproductive months, while the $\mathrm{DI}$ in the season was $4.9 \mathrm{larvae} / \mathrm{m}^{3}$, with the larvae group other species $\left(2.9 \mathrm{larvae} / \mathrm{m}^{3}\right)$ and bocachico (1.8 larvae $/ \mathrm{m}^{3}$ ) as the most abundant. Conclusions. Most reproductive activity was recorded early in the season (April and May) and parameters such as $Q_{\text {river }} T_{\text {river }}, V_{\text {river }}$ Pluv, STD and Nub may be considered final factors associated with migratory fish reproduction.
\end{abstract}

Key words: Abiotic factors, ichthyoplankton, fluvial, reproduction (Source: MeSH, DeCS, NLM).

\section{RESUMEN}

Objetivo. Caracterizar algunos factores abióticos durante la temporada reproductiva de los peces migratorios (bocachico Prochilodus magdalenae, dorada Brycon sinuensis, bagre blanco Sorubim cuspicaudus y barbul Pimelodus blochii) en el río Sinú. Materiales y métodos. Entre abril y octubre de 2008, en Carrizola (Tierralta, $36.31 \mathrm{~km}$ de la Hidroeléctrica Urrá) se midieron diariamente tres veces/ día $(07: 00 \mathrm{~h}, 12: 00 \mathrm{~h}, 17: 00 \mathrm{~h})$ factores como caudal $=\mathrm{Q}_{\text {rio }}$ diferencia de caudal $=\Delta \mathrm{Q}_{\text {rio }}$, velocidad $=\mathrm{V}_{\text {rio' }}$ temperatura $=\mathrm{T}_{\text {rio }}$, conductividad eléctrica $=C E$, sólidos totales disueltos $=S T D$, turbidez $=$ Turb, nubosidad=Nub, pluviosidad=Pluv y brillo solar=Bs; también, en el mismo horario, se recolectó ictioplancton como indicador de actividad reproductiva, evaluada mediante frecuencia reproductiva 
( $\mathrm{Fr}=$ número de días con presencia de ictioplancton/número de días del período evaluadoX100) y la densidad larval $\left(\mathrm{DI}=\right.$ larvas $\left./ \mathrm{m}^{3}\right)$. Resultados. Valores diarios de $\mathrm{Q}_{\text {rio }}$ oscilaron entre 278.7 y 838.5 $\mathrm{m}^{3} / \mathrm{s}, \Delta Q_{\text {rí }}$ entre 0.0 y $100.7 \mathrm{~m}^{3} / \mathrm{s}, V_{\text {río }}$ entre 1.40 y $1.53 \mathrm{~m} / \mathrm{s}$, Pluv entre 0.0 y $88.2 \mathrm{~mm}$, $T_{\text {río }}$ entre 27.0 y $28.7^{\circ} \mathrm{C}$, STD entre 73.0 y $302.3 \mathrm{mg} / \mathrm{L}$, Turb entre 9.7 y 679.7 NTU, CE entre 81.0 y $361.7 \mu \mathrm{S} /$ $\mathrm{cm}$, Bs entre 0.0 y 11.2 horas, Nub entre 2.0 y 7.3 octas. La Fr en el período fue de $30.4 \%$, con abril $(40.0 \%)$ y mayo $(74.2 \%)$ como los meses de mayor actividad reproductiva; la DI en el período fue de 4.9 larvas $/ \mathrm{m}^{3}$, con el grupo otras especies $\left(2.9 \mathrm{larvas} / \mathrm{m}^{3}\right)$ y bocachico $\left(1.8 \mathrm{larvas} / \mathrm{m}^{3}\right)$ más abundantes. Conclusiones. Mayor actividad reproductiva se registró al inicio de la temporada de lluvias (abril y mayo); con $\mathrm{Q}_{\text {rió }}, \mathrm{T}_{\text {rió }}, \mathrm{V}_{\text {rió }}$ Pluv, STD y Nub como factores finales asociados a la reproducción de los peces migradores.

Palabras clave: Factores abióticos, fluvial, ictioplancton, reproducción (Fuente: MeSH, DeCS, NLM).

\section{INTRODUCTION}

In fish, reproduction is a process controlled by external and internal factors; the external factors, which are of biotic type (predation, competition, sex ratio, population density, among other) and abiotic (flow, photoperiod, temperature, $\mathrm{pH}$, dissolved oxygen, electrical conductivity, among others) act in different moments and spaces of the reproductive cycle (1).

The abiotic factors can trigger and extend spawning and generate favorable conditions for the development of larva (2). Such conditions are considered environmental factors that stimulate spawning of migratory fish. In rivers that have been intervened by hydroelectric constructions, these incentives could be altered and thus, could affect the reproduction of fish (3).

In tropical atmospheres, the increase in water level, precipitation and electrical conductivity are considered key factors in fish reproduction (4). Jimenez-Segura et al (4) found that in the Magdalena river, the initial and proximate stimuli, which determine the start of the gonad maturity, were high solar illumination and high water temperatures during shallow water periods; while final or last factors, which determined the courtship and mating, were the reduction of solar illumination, as a result of the increase in cloudiness and the reduction of the temperature during high and rising water periods.

In the Sinu river basin there is little information about the abiotic factor characteristics during the reproductive season of migratory fish and which of these can be considered as final factors for reproduction incentives (mating and spawning); therefore, the objective of this study was to characterize some environmental abiotic factors and which are associated to the final stimuli for the reproduction of migratory fish such as the bocachico, dorada, bagre blanco and barbul in the Sinu river.

\section{INTRODUCCIÓN}

En peces, la reproducción es un proceso controlado por factores externos e internos; donde los externos, de tipo biótico (predación, competición, proporción de sexo, densidad de población, entre otros) y abióticos (caudal, fotoperíodo, temperatura, $\mathrm{pH}$, oxígeno disuelto, conductividad eléctrica, entre otros) actúan en diferentes momentos y espacios del ciclo reproductivo (1).

Los factores abióticos pueden desencadenar y prolongar el desove y proporcionar condiciones favorables para el desarrollo de las larvas (2), los cuales son considerados factores ambientales que estimulan el desove de los peces migratorios. En los ríos intervenidos por la construcción de hidroeléctricas estos estímulos pueden estar alterados y por ende afectar la reproducción de los peces (3).

En ambientes tropicales, el aumento del nivel del agua, la precipitación y la conductividad eléctrica son considerados factores determinantes en la reproducción de los peces (4). Jiménez-Segura et al (4) encontraron que en el río Magdalena, los estímulos iniciales o proximales, que determinan el inicio de la maduración de las gónadas, fueron la alta iluminación solar y las altas temperaturas del agua durante el período de aguas bajas; mientras que los factores finales o últimos, que determinaron el cortejo y apareamiento, fueron la reducción del brillo solar, como resultado del incremento en la nubosidad y la reducción de la temperatura en el período de aguas en ascenso y altas.

En la cuenca del río Sinú no existe mayor información sobre las características de los factores abióticos durante la temporada reproductiva de los peces migratorios y cuáles de estos pueden ser considerados como factores finales para el estímulo de la reproducción (apareamiento y desove); por lo tanto, el objetivo de este estudio fue caracterizar algunos factores ambientales abióticos y cuáles están asociados al estímulo final para la reproducción de peces migradores como bocachico, dorada, bagre blanco y barbul en el río Sinú. 


\section{MATERIALS AND METHODS}

Study location. The Sinu river begins in the town of Ituango, Antioch (Paramillo Massif), crosses the towns of Tierralta, Valencia, Montería, Cereté, San Pelayo, Cotorra, Lorica and San Bernardo del Viento, in the department of Cordoba, and ends at the Caribbean Sea, in the Tinajones delta area. The total length of the river is $437.97 \mathrm{~km}$, from its source until its mouth. At $267 \mathrm{~km}$ from its mouth, the Urra (HU) hydroelectric power plant was built, and therefore, the river is regulated by the operation of the hydroelectric plant.

In order to verify the presence of reophilic fish spawning, ichthyoplankton was collected daily between April 15 and October 15, 2008 (184 days), in the upper part of the Sinu river, at $36.3 \mathrm{~km}$ (North latitude $8^{\circ} 09^{\prime} 40.8^{\prime \prime}$ and West longitude $76^{\circ} 05^{\prime} 44.8^{\prime \prime}$ ) downstream from the HU (Carrizola, Tierralta, Cordoba). The period evaluated corresponded to the rainy season in the Sinu river basin. The ichthyoplankton was collected three times per day at 7:00, 12:00 and 17:00 hours, at a distance between 5 and $10 \mathrm{~m}$ from the right margin of the river, with superficial samples of 1 minute, using a simple conical plankton net with a mouth diameter of $50 \mathrm{~cm}$ and a $0.5 \mathrm{~mm}$ mesh opening; the samples were fixed in formalin $1 \%(\mathrm{v} / \mathrm{v})$ neutralized with monobasic and dibasic sodium phosphate and labeled in $50 \mathrm{ml}$ plastic jars. The ichthyoplankton were separated by species (bocachico, liseta, bagre blanco, barbul, and other species) at the Fish Research Center of the University of Cordoba (CINPIC) and their state of development was determined (blastomeration, blastulation, gastrulation, segmentation, pharyngulation). The identification was made based on embryonic and larva characteristics of the fish (5). To the embryos that were not identified, a development stage was determined, and they were counted and registered as other species (other spp.)

\section{Larval density and reproductive frequency.}

The estimation of the amount of larva collected from each sample was expressed as larval density per day ( $\mathrm{DI}$, larvae $/ \mathrm{m}^{3}$ ) using the following equation:

$$
D l=\frac{n}{\left\lfloor V_{\text {río }} \times t \times \text { Ared }\right\rfloor}
$$

Where:

$D I=$ larval Density by sampling (larvae $\left./ \mathrm{m}^{3}\right)$

$n=$ Number of ichthyoplankton collected by

sampling

$V_{\text {river }}=$ Speed of the river $\left(\mathrm{m}^{3} / \mathrm{s}\right)$

$t=$ collection Time $(60 \mathrm{~s})$

Ared $=$ Area of the net $\left(\mathrm{m}^{2}\right)$.

\section{MATERIALES Y MÉTODOS}

Sitio de estudio. El río Sinú nace en el municipio de Ituango, Antioquia (Nudo de Paramillo), atraviesa los municipios de Tierralta, Valencia, Montería, Cereté, San Pelayo, Cotorra, Lorica y San Bernardo del Viento, en el departamento de Córdoba, y desemboca en el mar Caribe, en la zona del delta de Tinajones. Tiene una longitud total de cauce de $437.97 \mathrm{~km}$, desde su nacimiento hasta su desembocadura. A 267 km de la desembocadura se construyó la hidroeléctrica Urrá (HU) por lo cual es un río regulado por la operación de la hidroeléctrica.

Con el fin de verificar la presencia de desoves de peces reofílicos, diariamente, entre el 15 de abril y 15 de octubre de 2008 (184 días), se recolectó ictioplancton en la parte alta del río Sinú, a $36.3 \mathrm{~km}$ (latitud Norte $8^{\circ} 09^{\prime} 40.8^{\prime \prime}$ y longitud Oeste $76^{\circ} 05^{\prime} 44.8^{\prime \prime}$ ) aguas abajo de la HU (Carrizola, Tierralta, Córdoba). El período evaluado correspondió a la temporada lluviosa en la cuenca del río Sinú. El ictioplancton fue recolectado tres veces al día en horarios de 07:00; $12: 00$ y 17:00 horas, a una distancia entre 5 y $10 \mathrm{~m}$ de la margen derecha del río, con muestreos superficiales de 1 minuto, utilizando una red de plancton cónica simple con diámetro de boca de $50 \mathrm{~cm}$ y ojo de malla de $0.5 \mathrm{~mm}$; las muestras se fijaron en formol $1 \%$ ( $/ \mathrm{v}$ ) neutralizado con fosfato de sodio monobásico y dibásico y rotuladas en frascos plásticos de $50 \mathrm{~mL}$. En el Centro de Investigación Piscícola de la Universidad de Córdoba (CINPIC), el ictioplancton fue separado por especie (bocachico, liseta, bagre blanco, barbul, otras especies) y se determinó su estado de desarrollo (blastomeración, blastulación, gastrulación, segmentación, faringulación). La identificación se realizó con base en las características embrionarias y larvarias de los peces (5). A los embriones que no fueron identificados, se les determinó su estado de desarrollo, se contaron y registraron como otras especies (otras spp.).

Densidad larval y frecuencia reproductiva. La estimación de la cantidad de larvas colectada en cada muestreo se expresó como densidad larval día (DI, larvas $/ \mathrm{m}^{3}$ ) utilizando la siguiente ecuación:

$$
D l=\frac{n}{\left\lfloor V_{\text {río }} \times t \times \text { Ared }\right\rfloor}
$$

Dónde:

$D /=$ Densidad larval por muestreo (larvas $/ \mathrm{m}^{3}$ )

$n=$ Número de ictioplancton colectado por muestreo

$V_{\text {rio }}=$ Velocidad del río $\left(\mathrm{m}^{3} / \mathrm{s}\right)$ 
Based on the three $D I$ samplings, the average larva per day $\left(D I_{d}\right)$ was estimated and based on this, the larva density per month $\left(D I_{m}\right)$ was estimated, only considering the days with presence of spawning (icthyoplankton).

The amount of days with reproductive activity of the migratory fish in the Sinu river during the reproductive season was called reproductive frequency (Rf), which was calculated by dividing the number of days with ichthyoplankton presence over the total number of days analyzed $x$ 100. Rf was estimated per month and for the whole evaluated period.

Hydraulic characteristics of the river during the reproductive period. The daily estimation of the river flow was conducted $\left(\mathrm{Q}_{\text {river }}\right)$, flow difference $\left(\Delta \mathrm{Q}_{\text {river }}\right)$ and river velocity $\left(\mathrm{V}_{\text {river }}\right)$. The $\mathrm{Q}_{\text {river }}$ and the $\mathrm{V}_{\text {rio }}$ were estimated three times per day (07: 00; 12:00 and 17:00 hours) based on the reading of the water level of the river, obtained at the IDEAM water level gauging Station in Carrizola (Tierralta, Cordoba); the river flow and an average velocity per day were calculated as well. The $\Delta Q_{\text {river }}$ was estimated from the river flow differences from one day to the next. The $Q_{\text {river, }}, V_{\text {river }}$ and water level gauging readings were adjusted through eight hydraulic gauging (two times per month during six months) which considered the measure of $\mathrm{V}_{\text {river }}$ and the $\mathrm{Q}_{\text {river }}$ at different depths (superficial, $20 \%$ and $80 \%$ depth) every eight meters in a section of the river at Carrizola (Tierralta) with the aid of flowmeters (A.OTT Kempten, C31-00, Germany) with propeller (2-38798, Germany), flow meter (A.OTT Kemptem, Typ 12,400, Germany) and winch (65645PKS, Germany).

Physicochemical characteristics of the river. The temperatures of the river $\left(T_{\text {river }}\right)$, the turbidity (Turb), the total dissolved solids (STD) and the electrical conductivity (CE), were measured during each collection of ichthyoplankton. The $\mathrm{T}_{\text {river }}$ was measured with a mercury thermometer with a precision of $\pm 0.5^{\circ} \mathrm{C}$ (BRIXCO, United Kingdom). Turb was measured with a portable digital turbidimeter (Orbeco-Hellige, the USA); whereas CE and STD were measured using a digital conductimeter (WTW, LF538, the USA). An average value per day for each one of these parameters was estimated from the three daily readings.

Characterization of rainfall (Pluv), solar brightness (Bs) and cloudiness (Nub). The daily records of Pluv, Bs and Nub, were obtained from the URRA I Weather Center Station, located at the dam (Tierralta, Córdoba). $t=$ Tiempo recolección $(60 \mathrm{~s})$

Ared $=$ Área de la red $\left(\mathrm{m}^{2}\right)$.

Con base en los tres muestreos de $D /$ se estimó la densidad larval promedio día $\left(D I_{d}\right)$ y con base en esta se estimó la densidad larval mensual $\left(D I_{m}\right)$, sólo considerando los días con presencia de desoves (ictioplancton).

La cantidad de días con actividad reproductiva de los peces migradores en el río Sinú en la temporada reproductiva se denominó frecuencia reproductiva ( $\mathrm{Fr}$ ), la cual se calculó dividiendo el número de días con presencia de ictioplancton sobre el número total de días analizados $\times 100$. La Fr se estimó por mes y para todo el período evaluado.

Características hidráulicas del río en el período reproductivo. Se realizó la estimación diaria de caudal $\left(\mathrm{Q}_{\text {rio }}\right)$, diferencia de caudal $\left(\Delta \mathrm{Q}_{\text {rio }}\right)$ y velocidad del río $\left(V_{\text {rio }}\right)$. El $Q_{\text {rio }}$ y la $V_{\text {rí }}$ fueron estimados tres veces al día (07:00; $12: 00$ y 17:00 horas) con base en la lectura del nivel del agua del río, obtenida de la Estación limnimétrica del IDEAM en Carrizola (Tierralta, Córdoba) y calculado un caudal y velocidad promedio por día. La $\Delta Q_{\text {rio }}$ fue estimada de las diferencias de caudal de un día para otro. El $Q_{\text {rio, }} V_{\text {rio }}$ y lecturas limnimétricas fueron ajustadas mediante la realización de ocho aforos hidráulicos (dos veces por mes durante seis meses) que consistieron en medir la $V_{\text {rio }}$ y el $Q_{\text {rio }}$ a diferentes profundidades (superficial, $20 \%$ y $80 \%$ de la profundidad) cada ocho metros en una sección del río a la altura de Carrizola (Tierralta) con la ayuda de un flujómetro (A.OTT Kempten, C31-00, Alemania) con hélice (2-38798, Alemania), contador de flujo (A.OTT Kemptem, Typ 12.400, Alemania) y un malacate (65645PKS, Alemania).

Características físico-químicas del río. Durante cada recolección de ictioplancton fueron medidas la temperatura del río $\left(T_{\text {rio }}\right)$, la turbidez (Turb), los sólidos totales disueltos (STD) y la conductividad eléctrica (CE). La $\mathrm{T}_{\text {rio }}$ se midió con un termómetro de mercurio con precisión de $\pm 0.5^{\circ} \mathrm{C}$ (BRIXCO, United Kingdom). La Turb con un turbidímetro digital portátil (Orbeco-Hellige, USA); mientras que CE y STD fueron medidos con ayuda de un conductímetro digital (WTW, LF538, USA). De las tres lecturas diarias se estimó un valor promedio por día para cada uno de estos parámetros.

Caracterización de pluviosidad (Pluv), brillo solar (Bs) y nubosidad (Nub). Los registros diarios de Pluv, Bs y Nub, fueron obtenidos de la Estación Meteorológica Central URRA I, localizada en el embalse (Tierralta, Córdoba). 
Statistical analysis. No environmental variable studied $\left(\mathrm{Q}_{\text {river }}, \Delta \mathrm{Q}_{\text {river }}, \mathrm{V}_{\text {river' }} \mathrm{T}_{\text {river }}\right.$ Turb, EC, STD, Pluv, Bs and Nub) or DI met the assumptions of normality (Shapiro-Wilk test) and homogeneity (Levene test). A descriptive statistic (average \pm standard deviation) of all environmental variables considered during every day of the study (184 days) and the days in which spawning presence (ichthyoplankton) was detected, was carried out. During the studied period, DI of the different species was compared though a non-parametric ANOVA (Kruskal-Wallis test) and when differences were observed, Dunnett's multiple comparison per pairs test was used $(p<0.05)$. To determine the association between the studied environmental variables and the reproduction of the fish (presence of ichthyoplankton), a correlation analysis (Spearman Coefficient) and a Main Component Analysis (ACP) was conducted. The data was transformed through Log $(\mathrm{Xi}+1)$ before their analysis. The statistical analysis was conducted with using of the Statgraphic Centurion (6) and XLSTAT (vs. 2011) programs.

\section{RESULTS}

Identification of ichthyoplankton by species. During the study period, 8284 embryos were captured, of which the most common reophilic species found were bocachico $(36.3 \%)$, dorada $(0.5 \%)$, bagre blanco $(1.6 \%)$ and barbul $(0.6 \%)$. Embryos of bocachico, barbul, bagre blanco and other species were captured predominantly in blastomeration stage; whereas the dorada was collected, mainly, in pharyngulation stage (Table 1 ). This group of species represented $61.1 \%$ of the total ichthyoplankton captured.

Reproductive frequency and larval density. In $30.4 \%$ of the days of the evaluated period (184

Table 1. Composition and stage of development of ichthyoplankton in the Sinu river in Carrizola (Tierralta) during April-October of 2008.

\begin{tabular}{lccccc}
\hline Species & Blas & $\begin{array}{c}\text { Gastru } \\
\text { (\%) }\end{array}$ & Togmen Pharyng \\
\hline Bocachico & 63.5 & 26.9 & 9.6. & 0.0 & 100.0 \\
Dorada & 0.0 & 0.0 & 25.0 & 75.0 & 100.0 \\
Bagre b. & 72.4 & 27.6 & 0.0 & 0.0 & 100.0 \\
Barbul & 82.9 & 0.0 & 14.7 & 2.4 & 100.0 \\
Other spp. & 68.7 & 27.1 & 4.2. & 0.0 & 100.0 \\
\hline
\end{tabular}

Blas= Blastomeration; Gastru= Gastrulation; Segmen=Segmentation; Pharyng=Pharyngulation spp. $=$ Species.
Análisis estadístico. Ninguna variable ambiental estudiada $\left(\mathrm{Q}_{\text {rio' }} \Delta \mathrm{Q}_{\text {rio }}, \mathrm{V}_{\text {rio' }} \mathrm{T}_{\text {rio' }}\right.$ Turb, CE, STD, Pluv, Bs y Nub) o DI cumplió los supuestos de normalidad (Shapiro-Wilk test) y homocedasticidad (Levene test). Se realizó estadística descriptiva (promedio \pm desviación estándar) de todas las variables ambientales considerando todos los días del estudio (184 días) y los días en los que se detectó presencia de desove (ictioplancton). La DI, en el período estudiado, de las diferentes especies fue comparada mediante un ANOVA no paramétrico (Kruskal-Wallis test) y cuando se observaron diferencias se utilizó la prueba de comparación múltiple por pares de Dunnett $(p<0.05)$. Para determinar la asociación entre las variables ambientales estudiadas y la reproducción de los peces (presencia de ictioplancton) se realizó un análisis de correlación (Coeficiente de Spearman) y un Análisis de Componentes Principales (ACP). Los datos, antes de ser analizados, fueron transformados mediante Log $(\mathrm{Xi}+1)$. El análisis estadístico fue realizado con la ayuda del programa Statgraphic Centurion (6) y XLSTAT (ver. 2011).

\section{RESULTADOS}

Identificación del ictioplancton por especie. Durante el período de estudio fueron capturados 8284 embriones, de los cuales las especies reofílicas más comunes encontradas fueron bocachico $(36.3 \%)$, dorada $(0.5 \%)$, bagre blanco $(1.6 \%)$ y barbul $(0.6 \%)$. Embriones de bocachico, barbul, bagre blanco y otras especies se capturaron predominantemente en estado de blastomeración; mientras que la dorada se colectó, principalmente, en estado de faringulación (Tabla 1). El grupo otras especies representó $61.1 \%$ del total del ictioplancton capturado.

Frecuencia reproductiva y densidad larval. En $30.4 \%$ de los días del período evaluado (184 días) se observó presencia de ictioplancton; siendo abril y mayo los meses con mayor Fr. Junio y julio mostraron una disminución de la $\mathrm{Fr}$; mientras que en agosto $(22.6 \%)$, septiembre $(26.7 \%)$ y octubre $(53.3 \%)$ se observó un leve incremento de la Fr (Tabla 2). Por especie se observó que en $30.4 \%$ del total de días estudiados se registró presencia de desoves del grupo otras especies, seguido por bocachico $(21.7 \%)$; mientras que bagre blanco $(5.4 \%)$, dorada $(3.8 \%)$ y barbul $(1.6 \%)$ registraron una baja $\mathrm{Fr}$.

La mayor $\mathrm{DI}_{\mathrm{m}}$ se registró en abril (19.8 larvas/ $\mathrm{m}^{3}$ ), la cual disminuyó con el transcurrir de los meses, alcanzando valores mínimos al final de la 
days), a presence of ichthyoplankton was observed; April and May were the months with more Fr. June and July showed a reduction in FR; while a slight increase of $\mathrm{Fr}$ was observed in August (22.6\%), September $(26.7 \%)$ and October(53.3\%) (Table 2 ). In $30.4 \%$ of the total studied days, a presence of spawning of the other group of species was observed, followed by the bocachico $(21.7 \%)$; while bagre blanco $(5.4 \%)$, dorada $(3.8 \%)$ and barbul $(1.6 \%)$ registered a decrease in $\mathrm{Fr}$.

The highest $\mathrm{DI}_{\mathrm{m}}$ was registered in April (19.8 larvae/ $\mathrm{m}^{3}$ ), which diminished with the passing of the months, reaching minimum values at the end of the reproductive season (September and October with $0.7 \pm 0.3$ and $1.2 \pm 0.3$ larvae $/ \mathrm{m}^{3}$, respectively). The highest $\mathrm{DI}_{\mathrm{m}}$ per species was registered for the group of other species $\left(2.9 \pm 1.7\right.$ larvae $\left./ \mathrm{m}^{3}\right)$ and bocachico $\left(1.8 \pm 1.7\right.$ larvae $\left./ \mathrm{m}^{3}\right)$. Ichthyoplankton from the other group of species was registered during the whole reproductive period; in September, no spawning of bocachico was registered. Dorada was observed during the first two months and during the fourth month of the study; while the bagre blanco was observed during the first four months of the study. Barbul was only registered in May (Table 3).

Environmental characteristic of the reproductive season of migratory fish. The daily $\mathrm{Q}_{\text {river }}$ during the study's period presented values that ranged between 278.7 and 838.5 $\mathrm{m}^{3} / \mathrm{s}$, with averages of $651.0 \mathrm{~m}^{3} / \mathrm{s}$. But when fish spawning appeared, the maximum values were $792.7 \mathrm{~m}^{3} / \mathrm{s}$ for the bocachico, dorada, bagre blanco and barbul species; and minimums values of 543.1 $3 \mathrm{~m}^{3} / \mathrm{s}$ for the group other species (Figure 1 ).

Table 2. Monthly reproductive frequency of spawning of migratory fish in the Sinu river in Carrizola (Tierralta) during April-October of 2008 (184 days).

\begin{tabular}{|c|c|c|c|c|c|c|}
\hline Months & Bocachico & Dorada & $\begin{array}{c}\text { Bagre b. } \\
(\%)\end{array}$ & Barbul & Other spp. & Total \\
\hline $\begin{array}{l}\text { April } \\
\text { (16) }\end{array}$ & 40.0 & 13.3 & 6.7 & 0.0 & 40.0 & 40.0 \\
\hline May & 58.1 & 6.5 & 16.1. & 9.7 & 74.2 & 74.2 \\
\hline June & 6.7 & 0.0 & 6.7 & 0.0 & 16.7 & 13.3 \\
\hline July & 12.9 & 6.5 & 6.5 & 0.0 & 12.9 & 12.9 \\
\hline August & 9.7 & 0.0 & 0.0 & 0.0 & 22.6 & 22.6 \\
\hline September & 0.0 & 0.0 & 0.0 & 0.0 & 10.0 & 26.7 \\
\hline $\begin{array}{l}\text { October } \\
(15)\end{array}$ & 46.7 & 6.7 & 0.0 & 0.0 & 53.3 & 53.3 \\
\hline $\begin{array}{c}\text { Total } \\
\text { period }\end{array}$ & 21.7 & 3.8 & 5.4. & 1.6 & 30.4 & 30.4 \\
\hline
\end{tabular}

temporada reproductiva (septiembre y octubre con $0.7 \pm 0.3$ y $1.2 \pm 0.3$ larvas $/ \mathrm{m}^{3}$, respectivamente). Las mayores $\mathrm{DI}_{\mathrm{m}}$ por especie se registraron para el grupo otras especies $\left(2.9 \pm 1.7\right.$ larvas $\left./ \mathrm{m}^{3}\right)$ y bocachico $\left(1.8 \pm 1.7\right.$ larvas $\left./ \mathrm{m}^{3}\right)$. El Ictioplancton del grupo otras especies fue registrado durante todo el período reproductivo; no se registraron desoves de bocachico en septiembre. Dorada se observó en los dos primeros meses y en el cuarto; mientras que bagre blanco se observó durante los primeros cuatro meses del estudio. Barbul sólo se registró en mayo (Tabla 3 ).

Característica ambiental de la temporada reproductiva de los peces migradores. $E_{I} Q_{r i o}$ diario durante el período de estudio, presentó valores que oscilaron entre 278.7 y $838.5 \mathrm{~m}^{3} / \mathrm{s}$, con promedios de $651.0 \mathrm{~m}^{3} / \mathrm{s}$. Pero cuando se presentaron desoves de peces los valores máximos fueron de $792.7 \mathrm{~m}^{3} / \mathrm{s}$ para las especies bocachico, dorada, bagre blanco y barbul; y mínimos de 543.1 $\mathrm{m}^{3} / \mathrm{s}$ para el grupo otras especies (Figura 1 ).

La $\Delta \mathrm{Q}_{\text {rio }}$ durante el período osciló entre 0.0 y 100.7 $\mathrm{m}^{3} / \mathrm{s}$. Cuando se presentaron desoves de especies como bocachico y bagre blanco, oscilaron entre 1.0 y $88.3 \mathrm{~m}^{3} / \mathrm{s}$; mientras que los desoves de dorada sucedieron con valores que oscilaron entre 1.0 y $92.1 \mathrm{~m}^{3} / \mathrm{s}$. Los desoves de barbul sucedieron con valores que oscilaron entre 1.0 y $100.7 \mathrm{~m}^{3} / \mathrm{s}$ (Figura 1).

La $\mathrm{V}_{\text {rio }}$ durante el período, mostró valores que oscilaron entre 1.40 y $1.53 \mathrm{~m} / \mathrm{s}$ y en ese intervalo se presentaron los desoves de los peces (Figura 1).

Table 3. Monthly larval density of spawning of migratory fish in the Sinu river in Carrizola (Tierralta) during April-October of 2008 (184 days).

\begin{tabular}{|c|c|c|c|c|c|c|}
\hline \multirow{2}{*}{$\begin{array}{c}\text { Months } \\
\begin{array}{c}\text { April } \\
(16)\end{array}\end{array}$} & \multicolumn{3}{|c|}{$\begin{array}{c}\text { Bocachico Dorada B. White } \\
\qquad / \mathrm{m}^{3}\end{array}$} & \multirow{2}{*}{$\begin{array}{c}\text { Barbul } \\
\\
0.0 \\
\pm 0.0\end{array}$} & \multirow{2}{*}{$\begin{array}{c}\begin{array}{c}\text { Other } \\
\text { spp. }\end{array} \\
11.8 \\
\pm 6.4\end{array}$} & \multirow{2}{*}{$\begin{array}{c}\text { Total } \\
19.8 . \\
\pm 5.5\end{array}$} \\
\hline & $\begin{array}{c}7.7 \\
\pm 7.7\end{array}$ & $\begin{array}{c}0.2 \\
\pm 0.3\end{array}$ & $\begin{array}{c}0.1 \\
\pm 0.1\end{array}$ & & & \\
\hline May & $\begin{array}{c}2.1 \\
\pm 2.8\end{array}$ & $\begin{array}{c}0.1 \\
\pm 0.2\end{array}$ & $\begin{array}{c}0.1 \\
\pm 0.1\end{array}$ & $\begin{array}{l}0.1 \\
\pm 0.1\end{array}$ & $\begin{array}{c}2.6 \\
\pm 1.8\end{array}$ & $\begin{array}{l}5.0 \\
\pm 1.2\end{array}$ \\
\hline June & $\begin{array}{c}0.1 \\
\pm 0.1\end{array}$ & $\begin{array}{c}0.0 \\
\pm 0.0\end{array}$ & $\begin{array}{c}0.1 \\
\pm 0.1\end{array}$ & $\begin{array}{c}0.0 \\
\pm 0.0\end{array}$ & $\begin{array}{c}2.2 \\
\pm 1.7\end{array}$ & $\begin{array}{c}2.4 \\
\pm 0.9\end{array}$ \\
\hline July & $\begin{array}{l}1.2 . \\
\pm 0.8\end{array}$ & $\begin{array}{c}0.1 \\
\pm 0.1\end{array}$ & $\begin{array}{c}0.2 \\
\pm 0.1\end{array}$ & $\begin{array}{c}0.0 \\
\pm 0.0\end{array}$ & $\begin{array}{c}1.5 \\
\pm 0.9\end{array}$ & $\begin{array}{c}3.0 \\
\pm 0.7\end{array}$ \\
\hline August & $\begin{array}{c}0.9 \\
\pm 0.3\end{array}$ & $\begin{array}{c}0.0 \\
\pm 0.0\end{array}$ & $\begin{array}{c}0.0 \\
\pm 0.0\end{array}$ & $\begin{array}{c}0.0 \\
\pm 0.0\end{array}$ & $\begin{array}{c}1.1 \\
\pm 0.3\end{array}$ & $\begin{array}{c}2.0 \\
\pm 0.6\end{array}$ \\
\hline September & $\begin{array}{c}0.0 \\
\pm 0.0\end{array}$ & $\begin{array}{c}0.0 \\
\pm 0.0\end{array}$ & $\begin{array}{c}0.0 \\
\pm 0.0\end{array}$ & $\begin{array}{c}0.0 \\
\pm 0.0\end{array}$ & $\begin{array}{c}0.7 \\
\pm 0.4\end{array}$ & $\begin{array}{c}0.7 \\
\pm 0.3\end{array}$ \\
\hline $\begin{array}{l}\text { October } \\
\text { (15) }\end{array}$ & $\begin{array}{c}0.6 \\
\pm 0.4\end{array}$ & $\begin{array}{c}0.0 \\
\pm 0.0\end{array}$ & $\begin{array}{c}0.0 \\
\pm 0.0\end{array}$ & $\begin{array}{c}0.0 \\
\pm 0.0\end{array}$ & $\begin{array}{c}0.5 \\
\pm 0.2\end{array}$ & $\begin{array}{l}1.2 . \\
\pm 0.3\end{array}$ \\
\hline Avg & $\begin{array}{c}1.8 \\
\pm 1.7^{\mathrm{a}}\end{array}$ & $\begin{array}{c}0.1 \\
\pm 0.1^{\mathrm{b}}\end{array}$ & $\begin{array}{c}0.1 \\
\pm 0.1^{\mathrm{b}}\end{array}$ & $\begin{array}{c}0.1 \\
\pm 0.1^{\mathrm{b}}\end{array}$ & $\begin{array}{c}2.9 \\
\pm 1.7^{\mathrm{a}}\end{array}$ & $\begin{array}{c}4.9 \\
\pm 1.4\end{array}$ \\
\hline
\end{tabular}

Different letters in the same row indicate significant differences $(p<0.05)$. $\mathrm{L}=$ larvae. $\mathrm{spp} .=$ Species. 

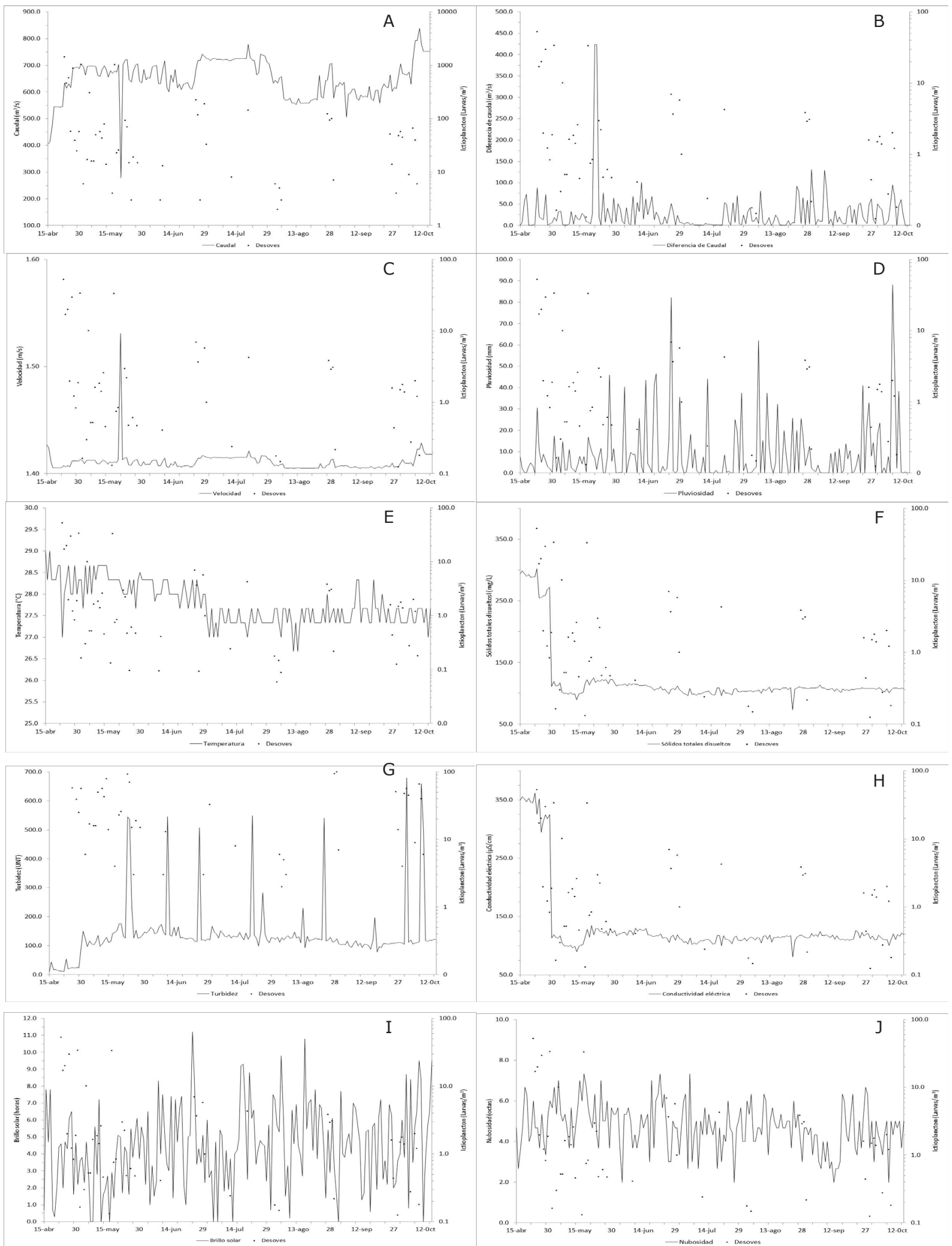

Figure 1. Variation of environmental factors in the Sinu river at Carrizola (Tierralta) during the 2008 reproductive season. a) River flow, b) river flow difference, c) river flow velocity, d) rainfall, e) temperature, f) total dissolved solids, g) turbidity, h) electric conductivity, i) solar brilliance and j) cloudiness. Black dots indicate days with spawning of migratory fish. 
$\Delta \mathrm{Q}_{\text {river }}$ during the period ranged between 0.0 and $100.7 \mathrm{~m}^{3} / \mathrm{s}$. When spawning of species like bocachico and bagre blanco appeared, the values ranged between 1.0 and $88.3 \mathrm{~m}^{3} / \mathrm{s}$; while the dorada spawning occurred with values that ranged between 1.0 and $92.1 \mathrm{~m}^{3} / \mathrm{s}$. Barbul spawning appeared with values that ranged between 1.0 and $100.7 \mathrm{~m}^{3} / \mathrm{s}$ (Figure 1 ).

$\mathrm{V}_{\text {river }}$ during the period showed values that ranged between 1.40 and $1.53 \mathrm{~m} / \mathrm{s}$ and fish spawning appeared during this period (Figure $1)$.

Pluv during the period of the study showed values that ranged between 0.0 and 1.53 and 88.2 $\mathrm{mm}$; during this same interval, migratory fish spawning appeared.

$\mathrm{T}_{\text {river }}$ during the reproductive season showed values that ranged between 26.7 and $29.0^{\circ} \mathrm{C}$; while spawning appeared in the interval between 27.0 and $28.7^{\circ} \mathrm{C}$ (Figure 1 ).

STD values during the period ranged between 73.0 and $302.3 \mathrm{mg} / \mathrm{L}$; dorada, bagre blanco and bocachico spawning appeared in this interval; while barbul spawning appeared in the interval between 99.3 and $119.0 \mathrm{mg} / \mathrm{L}$ (Figure 1).

Turb during the reproductive period ranged between 9.7 and 679.7 NTU (mean=139.1 NTU); bocachico, dorada (22.6-679.7 NTU) and bagre blanco (53.5-679.7 NTU) spawned in similar intervals; while barbul spawning appeared in the interval between 112.1 and 659.3 NTU (Figure 1).

CE during the reproductive period showed values that ranged between 81.0 and $361.7 \mu \mathrm{S} / \mathrm{cm}$. Bocachico, dorada and bagre blanco spawning appeared in a similar interval (81.0-325.7 $\mu \mathrm{S} /$ $\mathrm{cm})$; while barbul spawning appeared in an interval between 99.7-128.5 $\mathrm{sS} / \mathrm{cm}$ (Figure 1).

Bs values during the reproductive period ranged between 0.0 and 11.2 hours. The values were similar to those values of the period where the bocachico, dorada, bagre blanco and other species were recorded. Barbul spawning occurred with minimum values of 1.6 and maximum values of 7.5 hours (Figure 1 ).

Nub values during the period ranged between 2.0 and 7.3 octave; bochachico and barbul spawning appeared (2.0-7.0 octave) and dorada and bagre blanco (2.0-6.3 octave) in similar intervals (Figure 1 ).
La Pluv, durante el período de estudio mostró valores que oscilaron entre 0.0 y $88.2 \mathrm{~mm}$; en ese mismo intervalo se presentaron los desoves de los peces migratorios (Figura 1).

La $\mathrm{T}_{\text {rio' }}$ durante la temporada reproductiva mostró valores que oscilaron entre 26.7 y $29.0^{\circ} \mathrm{C}$; mientras que los desoves se presentaron en el intervalo de 27.0 y $28.7^{\circ} \mathrm{C}$ (Figura 1).

Los valores de STD durante el período oscilaron entre 73.0 y $302.3 \mathrm{mg} / \mathrm{L}$, en este intervalo se presentaron los desoves de dorada, bagre blanco y bocachico; mientras los desoves de barbul se presentaron entre 99.3 y 119.0 mg/L (Figura 1).

La Turb durante el período reproductivo osciló entre 9.7 y 679.7 NTU (media=139.1 NTU); bocachico, dorada (22.6-679.7 NTU) y bagre blanco (53.5-679.7 NTU) desovaron en intervalos similares; mientras que los desoves de barbul se presentaron entre 112.1 y 659.3 NTU (Figura 1).

La CE durante el período reproductivo mostró valores que oscilaron entre 81.0 y $361.7 \mu \mathrm{S} /$ $\mathrm{cm}$. Los desoves de bocachico, dorada y bagre blanco sucedieron en un intervalo similar (81.0$325.7 \mu \mathrm{S} / \mathrm{cm}$ ); mientras que barbul desovó en un intervalo entre 99.7-128.5 $\mu \mathrm{S} / \mathrm{cm}$ (Figura 1).

Los valores de Bs, durante el período reproductivo fluctuaron entre 0.0 y 11.2 horas. Estos valores fueron similares a los del período cuando se registraron desoves de bocachico, dorada, bagre blanco y otras especies. Los desoves de barbul sucedieron con valores mínimos de 1.6 y máximos de 7.5 horas (Figura 1).

Los valores de Nub durante el período oscilaron entre 2.0 y 7.3 octas; en intervalos similares se presentaron los desoves de bocachico y barbul (2.0-7.0 octas), y dorada y bagre blanco (2.0-6.3 octas), (Figura 1).

Correlación entre las variables ambientales y desoves de los peces migradores. $\mathrm{El}_{\mathrm{Q}_{\mathrm{i}}}$ $\mathrm{V}_{\text {rió }} \mathrm{T}_{\text {rio }} \mathrm{y}$ Pluv, fueron las variables que mayor número de relaciones significativas presentaron. Los desoves de bocachico están relacionados con $\mathrm{Q}_{\text {rió }}, \mathrm{V}_{\text {río }}$ y $\mathrm{T}_{\text {río }}$ así como los STD y la Pluv $(p<0.05)$. Los desoves de bagre blanco, al igual que bocachico, se correlacionaron directamente

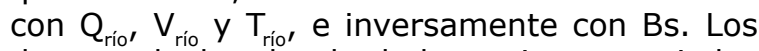
desoves de dorada y barbul estuvieron asociados con la Pluv y Nub, respectivamente. El grupo otras especies tuvo un comportamiento similar al bocachico correlacionándose con las $\mathrm{Q}_{\text {rio' }}, \mathrm{V}_{\text {rio' }}$ $\mathrm{T}_{\text {rio }}$ y Pluv (Tabla 4). 
Correlation between environmental variables and migratory fish spawning. $\mathrm{Q}_{\text {river, }}, \mathrm{V}_{\text {river }}, \mathrm{T}_{\text {river }}$ and Pluv, were the variables that showed the highest number of significant relations. Bocachico spawning is related to $Q_{\text {riverr }}$ $\mathrm{V}_{\text {river }}$ and $\mathrm{T}_{\text {river }}$ as well as STD and Pluv $(\mathrm{p}<0.05)$. Bagre blanco spawning, as well as bocachico spawning, were directly correlated to $Q_{\text {river }}, V_{\text {river }}$ and $\mathrm{T}_{\text {river }}$ and inversely correlated to Bs. Dorada and barbul spawning were associated with Pluv and Nub, respectively. The other species group had a similar behavior to the bocachico species correlating with $\mathrm{Q}_{\text {river, }}, \mathrm{V}_{\text {river, }} \mathrm{T}_{\text {river }}$ and Pluv (Table 4).

Table 4. Correlation between the environmental factors and the reproductive activity of the rheophilic fish in the Sinu river in Carrizola, Tierralta (April-October 2008).

\begin{tabular}{ccccccccccc}
\hline & \multicolumn{6}{c}{ ENVIRONMENTAL VARIABLES } \\
\hline Spawning & $\mathbf{Q}_{\text {river }}$ & $\boldsymbol{\Delta} \mathbf{Q}_{\text {river }}$ & $\mathbf{V}_{\text {river }}$ & $\mathbf{T}_{\text {river }}$ & $\mathbf{C E}$ & $\mathbf{S}$ STD Turb Nub Pluv & $\mathbf{B s}$ \\
\hline Bocachico & $\mathbf{0 . 3 1}$ & 0.07 & $\mathbf{0 . 2 8}$ & $\mathbf{0 . 1 9}$ & 0.04 & $\mathbf{0 . 1 7}$ & -0.04 & 0.09 & $\mathbf{0 . 2 7}$ & -0.06 \\
Dorada & 0.12 & 0.05 & 0.11 & 0.04 & 0.07 & 0.11 & -0.10 & 0.14 & $\mathbf{0 . 2 1}$ & 0.00 \\
Bagre b. & $\mathbf{0 . 1 8}$ & 0.02 & 0.17 & $\mathbf{0 . 1 8}$ & -0.03 & 0.00 & 0.03 & -0.01 & 0.06 & -0.15 \\
Barbul & 0.06 & 0.01 & 0.06 & 0.13 & 0.11 & 0.14 & 0.13 & 0.15 & 0.12 & -0.09 \\
Other spp. & $\mathbf{0 . 2 7}$ & 0.10 & $\mathbf{0 . 2 4}$ & $\mathbf{0 . 2 3}$ & 0.03 & 0.14 & -0.01 & 0.10 & $\mathbf{0 . 2 6}$ & -0.08
\end{tabular}

$\mathrm{Q}_{\text {river }}=$ Rive flow; $\Delta \mathrm{Q}_{\text {river }}=$ Difference of river flow; $\mathrm{V}_{\text {river }}=$ River velocity; $\mathrm{T}_{\text {river }}=$ River temperature; $\mathrm{CE}=$ electrical Conductivity; Total dissolved solids $\mathrm{STD}=$; Turb= Turbidity; Nub= Cloudiness; Pluv= Rainfall; $\mathrm{Bs}=$ Solar brilliance. Significant relations emphasized in bold. spp. $=$ Species.

Analysis of Main Components. In figure 2, the formation of two big groups can be observed: the first group is composed by the environmental variables $\mathrm{Q}_{\text {river }} \mathrm{V}_{\text {river' }} \mathrm{T}_{\text {river }}$ STD, Nub and Pluv, that showed a high relation with spawning of all type of reophilic species of the Sinu river; while the second group was composed by the environmental variables $\Delta Q_{\text {river }}, C E$, Turb and $B S$, which are not related with the main species of reophilic spawning in this river.

\section{DISCUSSION}

The collection of ichthyoplankton was composed, mainly, by migratory fish embryos of the Characiformes order (Prochilodus magdalenae and Brycon sinuensis) and the Siluriformes order (Sorubim cuspicaudus and Pimelodus blochii). According to Maldonado-Ocampo et al (7) of the 1435 fish species that live in Colombia's fresh water systems, the orders that make up the most species of the continent's ichthyofauna are Characiformes, with 637 species (44\%)
Análisis de Componentes Principales. En la figura 2, se observa la formación de dos grandes grupos: el primero conformado por las variables ambientales $\mathrm{Q}_{\text {rio' }}, \mathrm{V}_{\text {rio }}, \mathrm{T}_{\text {rio' }}$ STD, Nub y Pluv, que evidenciaron una alta asociación con los desoves de todas las especies reofílicas en el río Sinú; mientras que el segundo grupo estuvo conformado por las variables ambientales $\Delta \mathrm{Q}_{\text {rio' }}$ $\mathrm{CE}$, Turb y Bs, las cuales no están asociadas con los desoves de las principales especies reofílicas en este río.

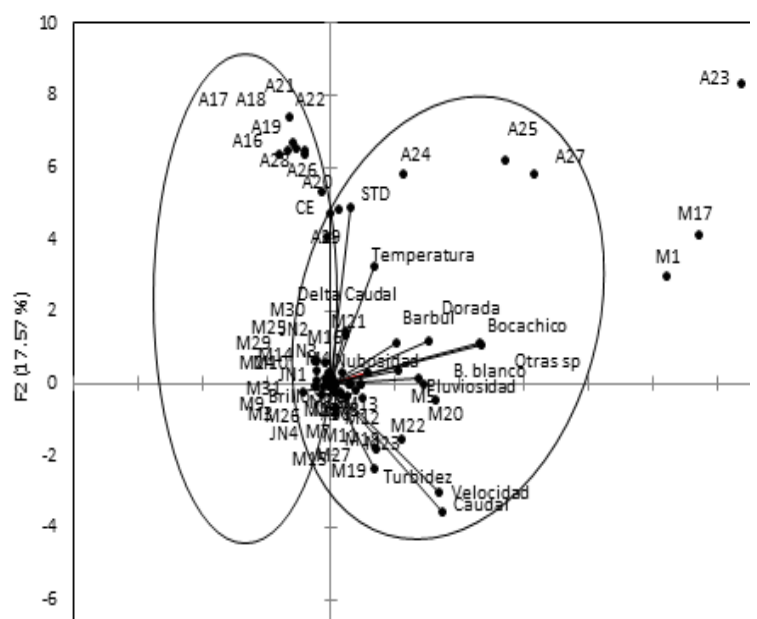

Figure 2. Biplot of the analysis of the main components for environmental variables and spawning in the Sinu river, Carrizola (Tierralta), during the 2008 reproductive season (April-October).

\section{DISCUSIÓN}

El ictioplancton colectado estuvo compuesto, principalmente, por embriones de peces migratorios de los órdenes Characiformes (Prochilodus magdalenae y Brycon sinuensis) y Siluriformes (Sorubim cuspicaudus y Pimelodus blochii). Según Maldonado-Ocampo et al (7) de las 1435 especies de peces que habitan los sistemas de agua dulce en Colombia, los órdenes que comprenden la mayoría de las especies de la ictiofauna continental son Characiformes con 637 especies (44\%) y Siluriformes con 524 especies (37\%). Jiménez-Segura et al (4), también reportaron que el $64 \%$ del ictioplancton en el río Magdalena, pertenece al grupo de peces migratorios de los órdenes Characiformes $(P$. magdalenae, Leporinus muyscorum, Curimata mivartii, Salminus affinis y Brycon sp.) y Siluriformes (Pimelodus spp., Pseudoplatystoma magdaleniatum, S. cuspicaudus). Asimismo en otros ríos de Suramérica, como en el río Uruguay, se encontró que la mayor abundancia de larvas colectadas pertenece al orden Characiformes (3). 
and Siluriformes, with 524 species (37\%). Jimenez-Segura et al (4), also reported that $64 \%$ of the ichthyoplankton of the Magdalena river belong to the migratory fish group of the Characiformes order ( $P$. magdalenae, Leporinus muyscorum, Curimata mivartii, Salminus affinis and Brycon sp.) and Siluriformes (Pimelodus spp., Pseudoplatystoma magdaleniatum, S. cuspicaudus). Also, in other South American rivers, such as the Uruguay river, it was found that the largest abundance of larva collected belongs to the Characiformes order (3).

When analyzing the results by species, it was observed that the highest $\mathrm{DI}$ in the Sinu river was shown by Prochilodus magdalenae, which is the most important species of the Colombian continental fisheries and the Prochilodus genus, which is the most abundant in species in the South American continental waters (7). Pimelodids S. cuspicaudus and $P$. blochii, showed the lowest larval abundance during the studies reproductive season.

Fr during the study's period indicated that the presence of ichthyoplankton was observed (reproductive activity) in only in $30.4 \%$ of the days. The months of April and May were the months with the most reproductive activity while in terms of frequency, like the DI (which suggests that despite spawning appearing during the studied period (April-October), the first two months (April-May) are the months of highest reproductive activity and of highest larval density when compared to the rest of the period. These results suggest that in the Sinu river basin the highest reproductive activity of migratory fish occurs at the beginning of the rainy season, stimulated by the variations of abiotic factors caused by the start of the first rainy period of the year.

The DI average of the estimated ichthyoplankton in Carrizola (Tierralta) as an indicator of the abundance of larval was 4.9 larvae $/ \mathrm{m}^{3}$, which is higher than the records reported in the Magdalena river (2.5 larvae $/ \mathrm{m}^{3}$ ) (4). It's possible that the difference between these numbers is due to the sampling structure; in this study, an estimated average for the entire reproductive season is presented (184 days), considering only the days with spawning presence; while in the Magdalena rive, the amount of days evaluated was 72 days in two years of study. Salete-Daga et al (8) reported larval densities of 2.9 individuals/ $\mathrm{m}^{3}$ in to floodable plains with different degrees of connection with the Parana river, Brazil; while Reynalte-Tatage et al (9) reported densities of 0.1 larvae $/ \mathrm{m}^{3}$ in the Ivinhema river, Brazil.
Al analizar los resultados por especie, se observó que la mayor DI en el río Sinú la presentó Prochilodus magdalenae, la cual es la especie más importante de la pesquería continental colombiana y el género Prochilodus el más abundante de las aguas continentales suramericanas (7). Los pimelódidos $S$. cuspicaudus y $P$. blochii, presentaron la menor abundancia larval durante la temporada reproductiva estudiada.

La Fr durante el período de estudio, señala que solamente en $30.4 \%$ de los días se observó presencia de ictioplancton (actividad reproductiva), con los meses de abril y mayo como los de mayor actividad reproductiva tanto en términos de frecuencia como de DI, lo cual permite sugerir que a pesar de presentarse desoves durante el período evaluado (abriloctubre), los dos primeros meses (abril-mayo) son los de mayor actividad reproductiva y los de mayor densidades larvales cuando se le compara con el resto del período. Estos resultados sugieren que en la cuenca del río Sinú la mayor actividad reproductiva de los peces migradores ocurre al inicio de la temporada de lluvias, estimulado por las variaciones de los factores abióticos ocasionadas por el inicio del primer período lluvioso del año.

La DI promedio del ictioplancton estimada en Carrizola (Tierralta), como indicador de abundancia larval fue de 4.9 larvas $/ \mathrm{m}^{3}$, que está por encima de los registros reportados en el río Magdalena (2.5 larvas $/ \mathrm{m}^{3}$ ) (4). Es posible que la diferencia entre estas cifras esté asociada a la estructura de muestreo; en el presente estudio se presenta un promedio estimado para toda la temporada reproductiva (184 días), considerando sólo los días con presencia de desoves; mientras que en el río Magdalena, la cantidad de días evaluados correspondió a 72 días en dos años de estudio. Salete-Daga et al (8), reportaron densidades larvales de 2.9 individuos $/ \mathrm{m}^{3}$ en dos planos inundables con diferentes grados de conexión con el río Paraná, Brasil, mientras que Reynalte-Tatage et al (9), reportaron densidades de 0.1 larvas $/ \mathrm{m}^{3}$ en el río Ivinhema, Brasil.

El río Sinú, a pesar de ser un río intervenido por la construcción de la $\mathrm{HU}$, presentó una fuerte variabilidad en los valores de los parámetros que describen la masa de agua, generado por la estacionalidad pluviométrica, que se caracteriza por desórdenes cíclicos y temporales durante la transición de aguas bajas a altas y viceversa. Las alteraciones ocasionadas por el aumento de los niveles de las aguas, se caracterizaron por incremento en el caudal del río, velocidad, conductividad eléctrica, turbidez y sólidos totales disueltos y reducción en la temperatura. Iguales 
The Sinu river, despite being a river intervened by the construction of the $\mathrm{HU}$, presented a strong variation in the values of the parameters that describe water mass caused by rainfall season, which is characterized by cyclical and temporary disorders during the transition between shallow and high waters and vice versa. The alterations caused by the increase in water levels are characterized by the increase in the river's flow, velocity, electric conductivity, turbidity and total dissolved solids and by the reduction of temperature. Similar conditions were reported for the Magdalena river with the difference that this river showed stronger daily fluctuations(4).

In this study, it was observed that spawning appeared when the river flows were above 790 $\mathrm{ms}^{3} / \mathrm{s}$; agreeing with Baumgartner et al's proposal (2), who considered that this condition was the only way for these species' larva to reach floodable plains that are not connected to the rivers during dry season. Both in the upper part of the Parana river as well as in the floodable plains, a higher DI of Pimelodus, Auchenipterus osteomystax and Iheringichthys labrosus was reported when the water level was high $(2,10)$.

In the Sinu river, the results suggest that the variables associated to the spawning of reophilic fish were the river's flow, velocity, temperature, rainfall, total dissolved solids, cloudiness and solar brilliance. Jiménez-Safe et al (4) suggest that in the Magdalena river during both annual hydrologic cycles (2004-2005), DI increased when a reduction in solar brilliant, an increase in cloudiness, an increase in rainfall and a fluctuation of synchronized water appeared with specific moments of low lunar brightness (4). In the upper part of the Uruguay river (Brazil), the abundance of eggs and larva showed a strong seasonal variation related to the higher flow values and water temperature as well as lower dissolved oxygen values, $\mathrm{pH}$ and transparency (3).

In the Sinu river, spawning of $P$. magdalenae, S. cuspicaudus and other species are related to more than three parameters, being the river's flow, velocity, temperature, and rainfall common factors in these species; while $B$. sinuensis and $P$. blochii were only correlated to rainfall and cloudiness, respectively. In the Magdalena river, DI of S. cuspicaudus, Pimelodus spp. and $P$. magdalenae was increased before the start of the currents when some reduction in solar brilliance was evident and the stability index began to decrease due to changes in the increase of rainfall and total dissolved solids (4).

In the high plains of the Portuguesa river (Venezuela), the presence of eggs between three condiciones fueron reportadas para el río Magdalena con la diferencia que este río presenta fluctuaciones diarias más marcadas (4).

En este estudio se observó que los desoves se presentaron cuando los caudales del río estuvieron por encima de $790 \mathrm{~m}^{3} / \mathrm{s}$; coincidiendo con lo propuesto por Baumgartner et al. (2), quienes consideraron esta condición como la única manera para que las larvas de estas especies lleguen a los planos inundables que no tienen conexión con los ríos durante la época seca. Tanto en la parte alta del río Paraná como en las planicies de inundación, fue reportada mayor DI de Pimelodus maculatus, Auchenipterus osteomystax y Iheringichthys labrosus cuando el nivel del agua se mantuvo alto $(2,10)$.

En el río Sinú, los resultados sugieren que las variables que estuvieron asociadas a los desoves de los peces reofílicos fueron caudal del río, velocidad, temperatura, pluviosidad, sólidos totales disueltos, nubosidad y brillo solar. Jiménez-Segura et al (4) sugieren que en el río Magdalena durante los dos ciclos hidrológicos anuales (2004-2005) la DI se incrementó cuando se presentó reducción del brillo solar, incremento de la nubosidad, incremento de la pluviosidad y fluctuación del nivel del agua sincronizados con momentos específicos de bajo brillo lunar (4). En el alto río Uruguay (Brasil), la abundancia de huevos y larvas presentó una marcada variación estacional, relacionada con los mayores valores de flujo y temperatura del agua y los menores valores de oxígeno disuelto, $\mathrm{pH}$ y transparencia (3).

En el río Sinú, los desoves de $P$. magdalenae, $S$. cuspicaudus y otras especies están relacionados con más de tres parámetros, donde caudal del río, velocidad, temperatura, pluviosidad son factores comunes en estas especies; mientras que $B$. sinuensis y $P$. blochii sólo se correlacionaron con pluviosidad y nubosidad respectivamente. En el río Magdalena, la DI de S. cuspicaudus, Pimelodus spp. y $P$. magdalenae se incrementó antes del comienzo de las crecientes, cuando se hizo evidente alguna reducción en el brillo solar y el índice de estabilidad comenzó a disminuir asociado a cambios en el incremento de pluviosidad y sólidos totales disueltos (4).

En los llanos altos del río Portuguesa (Venezuela), se registró la presencia de huevos entre tres y cinco veces por año, sólo cuando se observó aumento del nivel del río, con velocidades de las aguas entre 0.59 a $1.06 \mathrm{~m} / \mathrm{s}$ y generalmente luego del máximo nivel de inundación (11). En el alto río Uruguay (Brasil), se observaron huevos y larvas vitelínicas en los rápidos y desembocadura del río, con velocidades promedios entre 0.84 y $0.50 \mathrm{~m} / \mathrm{s}$ 
and five times per year was recorded only when an increase in the river's level was observed with water speeds between 0.59 to $1.06 \mathrm{~m} / \mathrm{s}$ and generally, after the maximum flood level (11). In the upper Uruguay river (Brazil), eggs and yolk-sac larvae in the river rapids and mouth, with average speeds between 0.84 and $0.50 \mathrm{~m} / \mathrm{s}$ were observed (3). In the Sinu river, these events were observed with average speeds above $1.41 \mathrm{~m} / \mathrm{s}$.

In the Sinu river, the electric conductivity was not related to spawning of migratory fish, but they were related to the temperature. In the Cuiba, Mato Gross river (Brazil), the higher densities of embryos and larvae are related to the places with low concentrations of dissolved oxygen, electric conductivity and transparency, larger width of the river and intermediate depths (12). In the flood plain of the upper Parana river, the electric conductivity was positively correlated with the ichthyoplankton density (8); likewise, a positive linear ratio was observed between the abundance of total larvae and the environmental conditions; which suggests that the higher abundance of larvae was related to higher values of electric conductivity and temperature (near $30^{\circ} \mathrm{C}$ ) (8).

In this study, the highest spawning of reophilic fish in the Sinu river appeared between April and May, when the temperature showed values between 27.0 and $28.7^{\circ} \mathrm{C}$. The highest reproductive intensity of many species of the Upper Parana river occurs between October and January (13), when the water temperatures are higher. Bialetzki et al (10) found strong relations between the ichthyoplankton community and the environmental variables in the Bahia river, mainly related with the temperature, the dissolved oxygen, the rainfall and the velocity. According to Jimenez-Segura (4) the photoperiod and the temperature are related to physicochemical processes associated with rainfall, such as the reduction in the intensity of solar brilliance, the increase in clouds and the increase in the water level, causing the reduction of the temperature.

In the Sinu river, the total dissolved solids were only correlated with $P$. magdalenae dissolves. In the Magdalena rive, the migratory fish spawning were related to total dissolved solids and the turbulence that characterizes the river currents period (4).

In the Sinu river, solar brilliance was only correlated inversely to S. cuspicaudus, spawning; whereas, in the river Magdalena, the change in maximum number of hours of solar brilliance between the months with higher and lower precipitation (about 2 hours), defined by temporary cloudiness patters, seem to define the chronology in the reproduction of reophilic fish (4).
(3). En el río Sinú, estos eventos se observaron con velocidades promedio por encima de $1.41 \mathrm{~m} / \mathrm{s}$.

En el río Sinú, la conductividad eléctrica no estuvo relacionada con los desoves de los peces migradores, pero sí la temperatura. En el río Cuiabá, Mato Grosso (Brasil), las mayores densidades de embriones y larvas están relacionadas con los sitios que presentan bajas concentraciones de oxígeno disuelto, conductividad eléctrica y transparencia, mayor ancho del río y profundidades intermedias (12). En la llanura aluvial del río Paraná superior, la conductividad eléctrica se correlacionó positivamente con la densidad del ictioplancton (8); de igual modo, se observó una relación lineal positiva entre la abundancia total de larvas y condiciones ambientales; sugiriendo que la mayor abundancia de larvas se asoció con altos valores de conductividad eléctrica y temperatura (cerca de $\left.30^{\circ} \mathrm{C}\right)$, (8).

En el presente estudio, los mayores desoves de los peces reofílicos en el río Sinú se presentaron entre abril y mayo, cuando la temperatura mostró valores entre 27.0 y $28.7^{\circ} \mathrm{C}$. La mayor intensidad reproductiva de muchas especies de peces en el río Paraná Superior ocurren entre octubre y enero (13), cuando las temperaturas del agua son más altas. Bialetzki et al (10), encontraron fuertes relaciones entre la comunidad del ictioplancton y las variables ambientales en el río Bahia, relacionados principalmente con la temperatura, oxígeno disuelto, pluviosidad y velocidad. Según Jimenez-Segura (4) el fotoperíodo y la temperatura están relacionados con procesos físico-químicos asociados con la pluviosidad, como reducción de la intensidad del brillo solar, incremento de las nubes e incremento del nivel del agua trayendo como consecuencia la reducción de la temperatura.

En el río Sinú, los sólidos totales disueltos estuvieron correlacionados, únicamente, con los desoves de $P$. magdalenae. En el río Magdalena, los desoves de los peces migratorios se relacionaron con los sólidos totales disueltos y la turbulencia que caracteriza el período de crecientes (4).

En el río Sinú, el brillo solar estuvo correlacionado de manera inversa, solamente, con los desoves de S. cuspicaudus, mientras que en el río Magdalena, el cambio de número de horas de máximo brillo solar entre los meses de mayor y menor precipitación (cercano a las 2 horas), definida por los patrones de nubosidad temporal, parecen definir la cronología en la reproducción de los peces reofílicos (4).

Los resultados del presente trabajo permiten concluir que la mayor actividad reproductiva, en términos de $\mathrm{Fr}$ y $\mathrm{DI}$, se presentó al inicio de la temporada de lluvias (abril y mayo). 
The results of this work allow to conclude that the highest reproductive activity, in terms of $\mathrm{Fr}$ and $\mathrm{DI}$, was at the beginning of the rainy season (April and May). The abiotic parameters of the river's flow, temperature, velocity, rainfall, total dissolved solids and cloudiness can be considered as final factors that stimulate the reproduction of reophilic fish. The spawning of $P$. magdalenae and S. cuspicaudus were stimulated by the river's flow, velocity and temperature; while the rainfall and the total dissolved solids stimulated the spawning of $P$. magdalenae. The spawning of $B$. sinuensis was stimulated only by rainfall; while the spawning of $P$. blochii was stimulated only by cloudiness.

\section{Acknowledgments}

To the Urra SA-ESP Hydroelectric for financing this study.
Los parámetros abióticos como caudal del río, temperatura, velocidad, pluviosidad, sólidos totales disueltos y nubosidad se pueden considerar factores finales que estimulan la reproducción de los peces reofílicos. Los desoves de $P$. magdalenae y $S$. cuspicaudus estuvieron estimulados por caudal del río, velocidad y temperatura; mientras que pluviosidad y sólidos totales disueltos estimularon los desoves de $P$. magdalenae. Los desoves de $B$. sinuensis estuvieron estimulados únicamente por la pluviosidad, mientras que los desoves de $P$. blochii estuvieron estimulados solo por la nubosidad.

\section{Agradecimientos}

A la empresa Hidroeléctrica Urrá SA-ESP por la financiación del presente estudio.

\section{REFERENCES}

1. Avendaño-Ibarra $R$, Funes-Rodríguez $R$, Hinojosa-Medina A, González-Armas R, AcevesMedina G. Seasonal abundance of fish larvae in a subtropical lagoon in the west coast of the Baja California Peninsula. Estuar Coast Shelf Sci 2004; 61(1):125-135.

2. Baumgartner G, Nakatani K, Gomes LC, Bialetzki A, Sanches PV, Makrakis MC. Fish larvae from the upper Paraná River: do abiotic factors affect larval density? Neotrop Ichthyol 2008; 6(4):551-558.

3. Alves Da Silva P, Reynalte-Tataje DA, ZaniboniFilho $E$. Identification of fish nursery areas in a free tributary of an impoundment region, upper Uruguay River, Brazil. Neotrop Ichthyol 2012; 10(2):425-438.

4. Jiménez-Segura LF, Palacio J, Leite R. River flooding and reproduction of migratory fish species in the Magdalena River basin, Colombia. Ecol Freshw Fish 2010; 19(2):178-186.

5. Arias-Gallo M, Jiménez-Segura LF, Dorado M Del P. Desarrollo larval de Prochilodus magdalenae (Steindachner, 1879) (Pisces: Prochilodontidae), río Magdalena, Colombia. Actual Biol 2010; 32(93):199-208.

6. Statistical Graphics Corp. Statgraphics Centurion 5.0. 2011.

7. Maldonado-Ocampo J, Vari R, Usma J. Checklist of the freshwater fishes of Colombia. Biota Colombiana 2008; 9(2):143-237.
8. Salete-Daga V, Gogola M, Vanderlei-Sanches $P$, Baumgartner G, Baumgartner D, Augusto Piana $P$, André Gubiani $E$, Luciana Delariva R. Fish larvae assemblages in two floodplain lakes with different degrees of connection to the Paraná River, Brazil. Neotrop Ichthyol 2009; 7(3):429-438.

9. Reynalte-Tataje DA, Nakatani $K$, Fernandes R, Agostinho AA, Bialetzki A. Temporal distribution of ichthyoplankton in the Ivinhema River (Mato Grosso do Sul State/ Brazil): Influence of environmental variables. Neotrop Ichthyol 2011; $9(2): 427-436$.

10. Bialetzki A, Nakatani K, Sanches PV, Baumgartner G, Gomes LC. Larval fish assemblage in the Bahia River (Mato Grosso do Sul State, Brazil): temporal and spatial patters. Environ Biol Fishes 2005; 73(1):37-47.

11. Rodríguez-Olarte $D$, Kossowski C. Reproducción de peces y consideración de ambientes en eventos de crecidas en el río Portuguesa, Venezuela. Rev Bioagro 2004; 16(2):143-147.

12. Ramalho Ziober S, Bialetzki A, Aparecida De Fátima Mateus $\mathrm{L}$. Effect of abiotic variables on fish eggs and larvae distribution in headwaters of Cuiabá River, Mato Grosso State, Brazil. Neotrop Ichthyol 2012; 10(1):123-132.

13. Gogola T, Daga $V$, Da Silva $P$, Sanches $P$, Gubiani É, Baumgartner G, Delariva R. Spatial and temporal distribution patterns of ichthyoplankton in a region affected by water regulation by dams. Neotrop Ichthyol 2010; 8(2):341-349. 